\title{
EGFR activating aberration occurs independently of other genetic aberrations or telomerase activation in adenocarcinoma of the lung
}

\author{
MARINA ARIFIN $^{1}$, KEIKO HIYAMA ${ }^{1}$, KEIJI TANIMOTO ${ }^{1}$, WIWIEN HERU WIYONO ${ }^{1,2}$, \\ EISO HIYAMA $^{3}$ and MASAHIKO NISHIYAMA ${ }^{1}$
}

${ }^{1}$ Department of Translational Cancer Research, Hiroshima University, Research Institute for Radiation Biology and Medicine,
Hiroshima, Japan; ${ }^{2}$ Department of Pulmonology and Respiratory Medicine, University of Indonesia, Jakarta, Indonesia;
${ }^{3}$ Natural Science Center for Basic Research and Development, Hiroshima University, Hiroshima, Japan

Received February 13, 2007; Accepted March 22, 2007

\begin{abstract}
The prognosis of lung cancer remains poor, and biological heterogeneity is largely responsible, especially in adenocarcinoma. We previously found that only one third of non-small cell lung cancer (NSCLC) but most small cell lung cancer (SCLC) tissues have strong telomerase activity, representing the difference in the history of multiple clonal selections. To reveal the genes differentially involved in telomerase activation mechanisms, we analyzed the relationship between common genetic aberrations and telomerase activity in 83 lung cancer tissues. We found that half (7 of 14) of lung adenocarcinomas with high telomerase activity showed neither TP53 nor RB1 deletion, while all squamous cell carcinomas and SCLCs with high telomerase activity showed loss of heterozygosity of at least one, if not both, of these suppressor oncogenes, indicating that these genetic aberrations are not required in activation of telomerase in a unique subset of adenocarcinoma. Furthermore, whereas the aberrations in TP53, RB1 and 1p34-pter were mutually related in 42 adenocarcinoma tissues, EGFR aberrations showed no relationship to either of them. These findings indicate that EGFR activating aberrations occur independently of other common genetic aberrations or telomerase activation mechanisms in lung adenocarcinoma, and that the distinct subset of lung adenocarcinoma with high telomerase activity without any common genetic aberrations may possibly have arisen from a telomerase-positive or telomerase-competent normal cell.
\end{abstract}

Correspondence to: Dr Keiko Hiyama, Department of Translational Cancer Research, Research Institute for Radiation Biology and Medicine, Hiroshima University, 1-2-3 Kasumi, Minami-ku, Hiroshima 734-8553, Japan

E-mail: khiyama@hiroshima-u.ac.jp

Key words: EGFR, telomerase, TP53, RB1, lung adenocarcinoma

\section{Introduction}

Lung cancer is a major cause of morbidity and mortality worldwide. In the last decade significant progress has been made in the understanding of the molecular mechanisms which are responsible for human cancer development and progression. A large number of chromosomal alterations and genetic defects have been identified in lung cancer $(1,2)$. Among them, inactivating aberrations of TP53 and RB1 genes and loss of heterozygosity ( $\mathrm{LOH}$ ) at various loci are frequently observed in lung cancer. Repeated clonal selection of cancer cells accumulating such genetic aberrations is considered to promote cellular immortalization concomitant with telomerase activation (3), encouraging novel anticancer strategies targeting telomere and telomerase (4-6). However, we recently found that carcinogenesis is not necessarily a prerequisite for activation of telomerase in lung cancer, and that the non-cancerous bronchial epithelia with telomerase expression have a predisposition to develop lung cancer (7). Then, to clarify the activation mechanism of telomerase in lung cancer, we here examined the relationship between genetic aberrations and activation of telomerase. As common genetic aberrations in lung cancer we analyzed TP53,RB1, and 1p34-pter deletions, which we previously found to be related with alteration with telomere length in lung cancer (8). As adenocarcinomacharacteristic aberrations, we investigated activating aberrations of EGFR and KRAS.

EGFR, a 170-kDa (1,186 amino acids) membrane-bound protein encoded by 28 exons spanning nearly 190,000 nucleotides on chromosome $7 \mathrm{p} 12$, is one member of the ErbB family of receptor tyrosine kinases which include four closely related receptors: HER-1/ErbB1, HER-2/neu/ErbB2, HER-3/ErbB3 and HER-4/ErbB4 (9-11). EGFR consists of an extracellular domain that binds EGF, transforming growth factor alpha (TGF- $\alpha$ ), and other growth factors, a short transmembrane region, and an intracellular tyrosine kinase domain. Ligand binding leads to homodimerization or heterodimerization of EGFR with other receptors then recruiting intracellular signaling proteins; converting extracellular signals to intracellular signal transduction events $(12,13)$. EGFR-activated pathway includes Akt and signal transducer and activator of 
transcription (STAT) cascades important for cell survival and mitogen-activated protein kinase (MAPK) pathway, which induces cell proliferation $(11,14)$. Dysregulation of these pathways appears to play a crucial role in oncogenesis and progression of solid tumors via effects on cell-cycle progression, inhibition of apoptosis, induction of angiogenesis, and promotion of tumor-cell motility and metastasis $(15,16)$. EGFR is known to be overexpressed in $40-80 \%$ of nonsmall cell lung cancers (NSCLCs) (15), suggesting that the activation of the EGFR signal pathway plays an important role in tumorigenesis of lung cancers. However, its activating aberrations, mutations and amplification, were revealed to be found solely in adenocarcinomas, giving them biologically distinct characteristics $(10,17,18)$. EGFR mutants may lead to abnormally sustained responses to EGF, activation of different downstream signaling pathways, and induction of distinct patterns of phosphotyrosine proteins (19-21). These EGFR mutants as well as amplified EGFR may transduce augmented survival signals, on which the cancer cells become dependent showing high sensitivity to gefitinib $(9,20,22)$. However, little is known of the relationship with activation of telomerase in cancer, and here we demonstrate that only EGFR activating aberrations occur independently of other molecular events common in lung cancer, including telomerase activation, while others relate with each other, and that there is a distinct subset in lung adenocarcinoma in which telomerase is highly activated without commonly known genetic aberrations.

\section{Materials and methods}

Tumor samples. We examined the relationship between various genetic aberrations and telomerase activity in 83 primary lung cancer tissues surgically resected from chemotherapy-naïve patients. We used corresponding adjacent non-cancerous lung tissue samples as control. All tissues were provided by the Departments of Pathology and Molecular and Internal Medicine, Hiroshima University between 1991-1996, with their pathological stages assessed according to the International Staging System (Hermanek and Sobin, 1987) and telomerase activity and chromosome $1 \mathrm{p}$ deletion mapping previously reported $(3,23)$. They consisted of 42 adenocarcinomas (male 24 , female 18), 30 squamous cell carcinomas (male 28, female 2), 7 small cell carcinomas (male 6 , female 1 ), and 4 adenosquamous carcinomas (male 4 , female 0 ). Written informed consent was obtained from all patients before surgery, and this study was approved by our Institutional Ethics Committee.

Telomerase activity and genetic aberrations. Among the genetic aberrations analyzed in this study, we previously reported the telomerase activity level (3) and 1p34 deletion mapping (23) for all samples, and loss of heterozygosity (LOH) of TP53 and RB1 genes and point mutation of the $K R A S$ gene (8) for some of them (Table I). The remaining samples were examined by the same procedure for this study. Briefly, genomic DNA was extracted from frozen tissues using proteinase $\mathrm{K}$ and SDS. LOH of the TP53 gene was assessed by PCR-based restriction fragment length polymorphisms (PCR-RFLPs) for the AccII site in exon 4 and the ApaI site in intron 7, polyacrylamide gel electrophoresis for a 16-nt insertion polymorphism in intron 3 , and fragment analysis for a 5-nucleotide microsatellite polymorphism in intron 1 and a dinucleotide microsatellite polymorphism at the 5'-flanking region of TP53 (X61505). LOH of the RB1 gene was assessed by PCR-RFLP for the $X b a \mathrm{I}$ site in intron 17 and fragment analysis for microsatellite markers in introns 2, 4 and 20 (8). $\mathrm{LOH}$ at $1 \mathrm{p} 34$-pter was assessed by deletion mapping at 12 loci (23) and mutations at the KRAS codons 12 and 13 were detected by designed PCR-RFLP (8) and confirmed by direct sequencing in the present study.

EGFR mutation analysis by direct sequencing. EGFR mutation was examined by direct sequencing for exons 18, 19, 20 and 21. The primers used for PCR were as follows (24): Exon 18, 18F: 5'-AGCATGGTGAGGGCTGAGGTGAC-3'; 18R: 5'ATATACAGCTTGCAAGGACTCTGG-3'. Exon 19, 19F: 5'-CCAGATCACTGGGCAGCATGTGGCACC-3'; 19R: 5'AGCAGGGTCTAGAGCAGAGCAGCTGCC-3'. Exon 20, 20F: 5'-GATCGCATTCATGCGTCTTCACC-3'; 20R: 5'TTGCTATCCCAGGAGCGCAGACC-3'. Exon 21, 21F: 5'TCAGAGCCTGGCATGAACATGACCCTG-3'; 21R: 5'-GG TCCCTGGTGTCAGGAAAATGCTGG-3'. Approximately $100 \mathrm{ng}$ of genomic DNA was amplified by PCR in $20 \mu 1$ reaction mixture containing $200 \mu \mathrm{M}$ each dNTP, $1.5 \mathrm{mM}$ $\mathrm{MgCl}_{2}, 0.5 \mathrm{mM}$ each primer, and $1 \mathrm{U}$ of AmpliTaqGold ${ }^{\mathrm{TM}}$ (Perkin-Elmer, NJ, USA). PCR amplification protocol was performed using a Program Temp Control System PC-818 (Astec, Fukuoka) for one initial cycle of $15 \mathrm{~min}$ at $95^{\circ} \mathrm{C}$, and 40 cycles of denaturation at $95^{\circ} \mathrm{C}$ for $60 \mathrm{sec}$, annealing at $66^{\circ} \mathrm{C}$ for $60 \mathrm{sec}$, and strand elongation at $72^{\circ} \mathrm{C}$ for $60 \mathrm{sec}$ were performed to amplify DNA fragments followed by a final elongation at $72^{\circ} \mathrm{C}$ for $5 \mathrm{~min}$. The PCR products were electrophoresed on a $2 \%$ agarose gel containing ethidium bromide. The PCR products were sequenced using BigDye ${ }^{\mathrm{TM}}$ Terminator v1.1 chemistry (Applied Biosystems, Foster City, CA, USA) in combination with an ABI PRISM ${ }^{\mathrm{TM}} 310$ genetic analyzer (Applied Biosystems). EGFR mutation loci were identified according to GenBank accession number NM_005228. All mutations were confirmed by at least two independent PCR amplifications.

EGFR amplification analysis by real-time PCR. EGFR copy number was determined by TagMan ${ }^{\mathrm{TM}}$ quantitative real-time PCR system with TagMan ${ }^{\mathrm{TM}}$ Universal PCR master mix and the ABI PRISM ${ }^{\mathrm{TM}}$ 7900HT sequence detection system (Applied Biosystems). The quantitative real-time EGFR amplification was performed with $20 \mathrm{ng}$ of genomic DNA in a 10- $\mu 1$ reaction mixture using a 384-well reaction plate (Applied Biosystems) and 2 sets of primers and probe: for EGFR and each control gene. The primer and MGB-probe sequences and final concentrations optimized for EGFR amplification analysis were as follows: EGFR (25), EGFR-F: 5'-CAATTG CCAGTTAACGTCTTCCTT-3', 300 nM; EGFR-R: 5'-TTTC TCACCTTCTGGGATCCA-3', 900 nM; EGFR-probe: FAMTCTCTCTGTCATAGGGAC, $200 \mathrm{nM}$. TFRC as different chromosome (chr. 3) control (26), TFRC-F: 5'-GCCAATGA GGTCTGAAATGGA-3', 300 nM; TFRC-R: 5'-GGCCTTAT TCCTGCAATCAACA-3', 900 nM; TFRC-probe: VIC-CTT CTGCTGGATAAAATGAGGTTCAA, $200 \mathrm{nM}$. COG5 as chromosome 7 control (25), COG5-F: 5'-TGGAAGATGAT GCACAAGATATATTCA-3', 300 nM; COG5-R: 5'-CCAA 
Table I. List of genetic aberrations in primary lung cancers with adenocarcinoma component.

$E G F R$

IVS1

No. Gender Age Stage Tel ${ }^{\mathrm{a}}$ TP53 RB1 $1 \mathrm{p} 34^{\mathrm{a}} \quad$ KRAS $\quad$ Mut/Amp ex20 repeat no.

\begin{tabular}{|c|c|c|c|c|c|c|c|c|c|c|c|}
\hline \\
\hline \multicolumn{12}{|c|}{$\begin{array}{l}\text { Adenocarcinoma } \\
1\end{array}$} \\
\hline 2 & $\mathrm{M}$ & 69 & I & Low & Hetero $^{\mathrm{a}}$ & Hetero $^{a}$ & Hetero & $\mathrm{w} / \mathrm{w}^{\mathrm{a}}$ & $\mathrm{w} / \mathrm{w}$ & $\mathrm{w} / \mathrm{w}$ & $18 / 20$ \\
\hline 3 & $\mathrm{M}$ & 75 & I & Low & Hetero & Hetero & Hetero & $\mathrm{w} / \mathrm{w}$ & $\mathrm{w} / \mathrm{w}$ & $\mathrm{w} / \mathrm{w}$ & $15 / 16$ \\
\hline 4 & $\mathrm{M}$ & 62 & I & Low & Hetero $^{a}$ & Hetero $^{a}$ & Hetero & $\mathrm{w} / \mathrm{w}^{\mathrm{a}}$ & $\mathrm{w} / \mathrm{w}$ & $\mathrm{w} / \mathrm{v}$ & $16 / 20$ \\
\hline 5 & M & 66 & I & Low & Hetero $^{a}$ & Hetero $^{\mathrm{a}}$ & Hetero & $\mathrm{w} / \mathrm{w}^{\mathrm{a}}$ & Amp & $\mathrm{w} / \mathrm{v}$ & 20 \\
\hline 6 & $\mathrm{~F}$ & 67 & I & Low & Hetero & Hetero & Hetero & $\mathrm{w} / \mathrm{w}$ & del746-750 & $\mathrm{w} / \mathrm{w}$ & $16 / 20$ \\
\hline 7 & $\mathrm{~F}$ & 67 & II & Low & Hetero $^{a}$ & Hetero $^{\mathrm{a}}$ & Hetero & $\mathrm{w} / \mathrm{w}^{\mathrm{a}}$ & $\mathrm{w} / \mathrm{w}$ & $\mathrm{w} / \mathrm{w}$ & 20 \\
\hline 8 & $\mathrm{M}$ & 76 & IIIA & Low & Hetero & Hetero & Hetero & $\mathrm{w} / \mathrm{w}$ & $\mathrm{w} / \mathrm{w}$ & $\mathrm{w} / \mathrm{v}$ & $16 / 20$ \\
\hline 9 & $\mathrm{M}$ & 61 & IIIA & Low & Hetero & Hetero & Hetero & $\mathrm{w} / \mathrm{w}$ & $\mathrm{w} / \mathrm{w}$ & $\mathrm{w} / \mathrm{w}$ & 20 \\
\hline 10 & $\mathrm{M}$ & 60 & IIIB & Low & Hetero & Hetero & Hetero & $\mathrm{w} / \mathrm{w}$ & $\mathrm{w} / \mathrm{w}$ & $\mathrm{w} / \mathrm{w}$ & 20 \\
\hline 11 & $\mathrm{~F}$ & 64 & IV & Low & Hetero $^{a}$ & Hetero $^{\mathrm{a}}$ & Hetero & $\mathrm{w} / \mathrm{w}^{\mathrm{a}}$ & $\mathrm{w} / \mathrm{w}$ & $\mathrm{w} / \mathrm{v}$ & $16 / 20$ \\
\hline 12 & $\mathrm{M}$ & 56 & IV & Low & Hetero $^{a}$ & Hetero $^{a}$ & Hetero & $\mathrm{w} / \mathrm{w}^{\mathrm{a}}$ & $\mathrm{w} / \mathrm{w}$ & $\mathrm{w} / \mathrm{v}$ & 20 \\
\hline 13 & $\mathrm{~F}$ & 57 & IIIA & Low & Hetero & Hetero & $\mathrm{LOH}$ & $\mathrm{w} / \mathrm{w}$ & $\mathrm{w} / \mathrm{w}$ & $\mathrm{w} / \mathrm{w}$ & $17 / 20$ \\
\hline 14 & $\mathrm{M}$ & 60 & IV & Low & Hetero $^{a}$ & Hetero $^{a}$ & $\mathrm{LOH}$ & $\mathrm{w} / \mathrm{w}^{\mathrm{a}}$ & $\mathrm{w} / \mathrm{w}$ & $\mathrm{w} / \mathrm{w}$ & 20 \\
\hline 15 & $\mathrm{~F}$ & 65 & IV & Low & Hetero $^{a}$ & Hetero $^{a}$ & $\mathrm{LOH}$ & $\mathrm{w} / \mathrm{w}^{\mathrm{a}}$ & del746-750 & $\mathrm{w} / \mathrm{w}$ & 20 \\
\hline 16 & $\mathrm{~F}$ & 62 & I & Low & Hetero $^{a}$ & $\mathrm{LOH}^{\mathrm{a}}$ & $\mathrm{LOH}$ & $\mathrm{w} / \mathrm{w}^{\mathrm{a}}$ & del747-51 & $\mathrm{w} / \mathrm{v}$ & 20 \\
\hline 17 & $\mathrm{~F}$ & 60 & I & Low & NI & Hetero & Hetero & $\mathrm{w} / \mathrm{w}$ & $\mathrm{w} / \mathrm{w}$ & $\mathrm{w} / \mathrm{v}$ & $20 / 22$ \\
\hline 18 & M & 48 & I & Low & $\mathrm{NI}^{\mathrm{a}}$ & Hetero $^{\mathrm{a}}$ & $\mathrm{LOH}$ & $\mathrm{w} / \mathrm{w}^{\mathrm{a}}$ & $\mathrm{w} / \mathrm{w}$ & $\mathrm{w} / \mathrm{w}$ & 20 \\
\hline 19 & $\mathrm{~F}$ & 51 & IIIa & Low & NI & Hetero & Hetero & $\mathrm{w} / \mathrm{w}$ & $\mathrm{w} / \mathrm{w}$ & $\mathrm{w} / \mathrm{v}$ & $15 / 20$ \\
\hline 20 & $\mathrm{~F}$ & 57 & I & Low & $\mathrm{LOH}$ & Hetero & $\mathrm{LOH}$ & $\mathrm{w} / \mathrm{w}$ & $\mathrm{w} / \mathrm{w}$ & $\mathrm{w} / \mathrm{w}$ & $17 / 20$ \\
\hline 21 & $\mathrm{M}$ & 58 & IV & Low & $\mathrm{LOH}^{\mathrm{a}}$ & Hetero $^{\mathrm{a}}$ & Hetero & $\mathrm{w} / \mathrm{w}^{\mathrm{a}}$ & L858R,Amp & $\mathrm{w} / \mathrm{v}$ & $17 / 20$ \\
\hline 22 & $\mathrm{~F}$ & 56 & IV & Low & $\mathrm{LOH}^{\mathrm{a}}$ & Hetero $^{a}$ & Hetero & $\mathrm{G} 12 \mathrm{C} / \mathrm{w}$ & $\mathrm{w} / \mathrm{w}$ & $\mathrm{w} / \mathrm{v}$ & 20 \\
\hline 23 & $\mathrm{M}$ & 66 & IV & Low & $\mathrm{LOH}^{\mathrm{a}}$ & Hetero $^{\mathrm{a}}$ & Hetero & $\mathrm{G} 12 \mathrm{C} / \mathrm{w}$ & $\mathrm{w} / \mathrm{w}$ & $w / v$ & 20 \\
\hline 24 & $\mathrm{~F}$ & 72 & IIIA & Low & $\mathrm{LOH}^{\mathrm{a}}$ & $\mathrm{LOH}^{\mathrm{a}}$ & Hetero & $\mathrm{w} / \mathrm{w}^{\mathrm{a}}$ & $\mathrm{w} / \mathrm{w}$ & $\mathrm{w} / \mathrm{w}$ & $20 / 22$ \\
\hline 25 & $\mathrm{M}$ & 67 & I & Low & $\mathrm{LOH}$ & $\mathrm{LOH}$ & $\mathrm{LOH}$ & $\mathrm{w} / \mathrm{w}$ & del746-50 & $\mathrm{w} / \mathrm{w}$ & 20 \\
\hline 26 & $\mathrm{M}$ & 77 & I & Low & $\mathrm{LOH}^{\mathrm{a}}$ & $\mathrm{LOH}^{\mathrm{a}}$ & $\mathrm{LOH}$ & $\mathrm{w} / \mathrm{w}^{\mathrm{a}}$ & $\mathrm{w} / \mathrm{w}$ & $w / v$ & $20 / 21$ \\
\hline 27 & $\mathrm{M}$ & 64 & I & Low & $\mathrm{LOH}$ & $\mathrm{LOH}$ & $\mathrm{LOH}$ & $\mathrm{w} / \mathrm{w}$ & $\mathrm{w} / \mathrm{w}$ & $\mathrm{w} / \mathrm{w}$ & $20 / 23$ \\
\hline 28 & $\mathrm{M}$ & 62 & IIIA & Low & Hetero $^{\mathrm{a}}$ & $\mathrm{LOH}^{\mathrm{a}}$ & $\mathrm{LOH}$ & $\mathrm{w} / \mathrm{w}^{\mathrm{a}}$ & $\mathrm{w} / \mathrm{w}$ & $\mathrm{w} / \mathrm{w}$ & 16 \\
\hline 29 & $\mathrm{~F}$ & 78 & I & High & Hetero & Hetero & Hetero & $\mathrm{w} / \mathrm{w}$ & $\mathrm{w} / \mathrm{w}$ & $\mathrm{w} / \mathrm{w}$ & $16 / 20$ \\
\hline 30 & $\mathrm{M}$ & 69 & I & High & Hetero & Hetero & Hetero & $\mathrm{w} / \mathrm{w}$ & $\mathrm{w} / \mathrm{w}$ & $\mathrm{w} / \mathrm{v}$ & 15 \\
\hline 31 & $\mathrm{M}$ & 62 & I & High & Hetero & Hetero & Hetero & $\mathrm{w} / \mathrm{w}$ & $\mathrm{w} / \mathrm{w}$ & $\mathrm{w} / \mathrm{w}$ & 20 \\
\hline 32 & $\mathrm{M}$ & 75 & I & High & Hetero $^{a}$ & Hetero $^{\mathrm{a}}$ & Hetero & $\mathrm{w} / \mathrm{w}^{\mathrm{a}}$ & $\mathrm{w} / \mathrm{w}$ & $\mathrm{w} / \mathrm{w}$ & 20 \\
\hline 33 & $\mathrm{~F}$ & 62 & II & High & Hetero & Hetero & Hetero & $\mathrm{w} / \mathrm{w}$ & del746-50,Amp & $\mathrm{w} / \mathrm{v}$ & 20 \\
\hline 34 & $\mathrm{~F}$ & 69 & IIIA & High & Hetero & Hetero & Hetero & $\mathrm{w} / \mathrm{w}$ & $\mathrm{w} / \mathrm{w}$ & $\mathrm{w} / \mathrm{v}$ & 15 \\
\hline 35 & $\mathrm{~F}$ & 77 & IV & High & Hetero $^{\mathrm{a}}$ & Hetero $^{a}$ & Hetero & $\mathrm{w} / \mathrm{w}^{\mathrm{a}}$ & $\mathrm{w} / \mathrm{w}$ & $w / v$ & 20 \\
\hline 36 & $\mathrm{~F}$ & 80 & I & High & Hetero $^{a}$ & $\mathrm{LOH}^{\mathrm{a}}$ & Hetero & $\mathrm{w} / \mathrm{w}^{\mathrm{a}}$ & $\operatorname{del} 747-51$ & $\mathrm{w} / \mathrm{w}$ & 20 \\
\hline 37 & $\mathrm{~F}$ & 59 & IIIA & High & $\mathrm{LOH}$ & Hetero & Hetero & $\mathrm{w} / \mathrm{w}$ & $\mathrm{w} / \mathrm{w}$ & $\mathrm{w} / \mathrm{w}$ & $16 / 20$ \\
\hline 38 & $\mathrm{M}$ & 76 & IIIA & High & $\mathrm{LOH}$ & Hetero & $\mathrm{LOH}$ & $\mathrm{w} / \mathrm{w}$ & Amp & $\mathrm{w} / \mathrm{w}$ & 20 \\
\hline 39 & $\mathrm{M}$ & 55 & I & High & $\mathrm{LOH}^{\mathrm{a}}$ & $\mathrm{LOH}^{\mathrm{a}}$ & $\mathrm{LOH}$ & $\mathrm{w} / \mathrm{w}^{\mathrm{a}}$ & ins773-6,Amp & $\mathrm{w} / \mathrm{w}$ & 20 \\
\hline 40 & $\mathrm{M}$ & 68 & II & High & $\mathrm{LOH}$ & $\mathrm{LOH}$ & $\mathrm{LOH}$ & $\mathrm{w} / \mathrm{w}$ & $\mathrm{w} / \mathrm{w}$ & $\mathrm{w} / \mathrm{w}$ & 20 \\
\hline 41 & M & 66 & IV & High & $\mathrm{LOH}$ & $\mathrm{LOH}$ & Hetero & $\mathrm{w} / \mathrm{w}$ & $\mathrm{w} / \mathrm{w}$ & $\mathrm{v} / \mathrm{v}$ & 20 \\
\hline 42 & $\mathrm{M}$ & 50 & IIIB & High & $\mathrm{LOH}^{\mathrm{a}}$ & $\mathrm{LOH}^{\mathrm{a}}$ & $\mathrm{LOH}$ & $\mathrm{w} / \mathrm{w}^{\mathrm{a}}$ & $\mathrm{w} / \mathrm{w}$ & $\mathrm{w} / \mathrm{v}$ & $16 / 20$ \\
\hline
\end{tabular}

Adenosquamous carcinoma

$\begin{array}{llllllllllll}43 & \text { M } & 75 & \text { IIIA } & \text { Low } & \text { Hetero }^{a} & \text { Hetero }^{a} & \text { Hetero } & \text { w/w } & \text { w/w } & \text { w/w } & 16 / 20 \\ 44 & \text { M } & 42 & \text { I } & \text { Low } & \text { NI } & \text { LOH } & \text { Hetero } & \text { G13D/w } & \text { w/w } & \text { w/v } & 20 \\ 45 & \text { M } & 75 & \text { IV } & \text { Low } & \text { LOH }^{a} & \text { LOH }^{a} & \text { Amp } & \text { w/w } & \text { w/w } & \text { w/w } & 20 \\ 46 & \text { M } & 69 & \text { IIIA } & \text { High } & \text { LOH } & \text { LOH } & \text { LOH } & \text { w/w } & \text { w/w } & \text { w/w } & 20\end{array}$

aPreviously reported: all tel, telomerase activity $(3,23)$; all 1p34, deletion mapping from 1p34 to pter (23); and cases of TP53, LOH in the $T P 53$ gene; $R B 1$, LOH in the $R B 1$ gene; and $K R A S$, mutations in codon 12 or 13 (8). Others are the present results. 


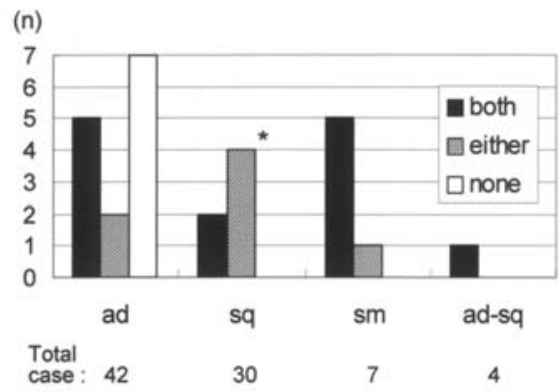

Figure 1. Frequencies of loss of heterozygosity (LOH) in TP53 and RB1 genes in lung cancer with high telomerase activity. ad, adenocarcinoma (total cases: $n=42)$; sq, squamous cell carcinoma $(n=30)$; sm, small cell carcinoma $(\mathrm{n}=7)$; ad-sq, adenosquamous carcinoma $(\mathrm{n}=4)$. "Including one non-informative case for $R B 1$ with $\mathrm{LOH}$ for $T P 53$.

CTAACAGGTCAAATTAAACAAACA-3', 300 nM; COG5probe: VIC-CCAAAAAAGCCAGATTATGA, $50 \mathrm{nM}$. The relative genomic copy number was calculated using the comparative threshold method. Threshold cycle $(\mathrm{Ct})$ for each gene was determined using thermocycler software and the average of 3 independent Cts was calculated. EGFR amplification was defined when the differences in the threshold amplification cycles between target gene $(E G F R)$ and different chromosome control gene (TFRC) were $\geq 0.8$. This cut-off value was based on the differences in the adjacent non-cancerous lung tissues.

Genotyping of EGFR intron 1 polymorphism and assessment of allelic imbalance by fragment analysis. Genomic DNA of tumor tissues was subjected to PCR using a FAM-labeled forward primer (5'-FAM-GGGCTCACAGCAAACTTCTC-3') and a non-labeled reverse primer (5'-AAGCCAGACTCGCT CATGTT-3') (27) with annealing temperature at $55^{\circ} \mathrm{C}$. The PCR products were analyzed by ABI PRISM 310 genetic analyzer and GeneScan ${ }^{\mathrm{TM}}$ software (Applied Biosystems). (CA)n repeat number was determined by the fragment size and confirmed by direct sequence of the representative sample. Allelic imbalance was defined when the peak height ratio of heterozygous bands was $<50 \%$ or $>200 \%$ of expected ratio calculated from the normal cells.

Statistical analysis. For statistical analysis, the relationship between EGFR activating aberrations and adenocarcinoma subgroups or other genetic changes was assessed by $\chi^{2}$ or Fisher's exact tests, as appropriate. Differences of $\mathrm{P}<0.05$ were considered statistically significant.

\section{Results}

Telomerase activity and LOH in TP53 and RB1. Among the 83 primary lung cancers, high telomerase activity [6 $\mu \mathrm{g}$ of protein extract expressed comparable TRAP signals with those using 100 or more immortal cancer cells in TRAP assay (3)] was found in 14 of 42 adenocarcinomas (33.3\%), 6 of 30 squamous cell carcinomas $(20.0 \%)$, 6 of 7 small cell carcinomas $(85.7 \%)$, and 1 of 4 adenosquamous carcinomas (25.0\%), and LOH of TP53 and RBI was found in 15 (35.7\%) and $11(26.2 \%)$ adenocarcinomas, $21(70.0 \%)$ and $12(40.0 \%)$ squamous cell carcinomas, 7 (100\%) and $5(71.4 \%)$ small cell carcinomas, and $2(50.0 \%)$ and $3(75.0 \%)$ adenosquamous carcinomas, respectively. While half of 14 adenocarcinomas with high telomerase activity showed neither TP53 nor RB1 aberrations, all remaining 13 tumors with high telomerase activity in other histology showed TP53 and/or RB1 aberrations (Fig. 1).

EGFR and KRAS aberrations in lung adenocarcinomas and adenosquamous carcinomas. Since only in adenocarcinoma, half of tumors with high telomerase activity showed neither TP53 nor RB1 aberrations, we surveyed EGFR and KRAS mutations, known as adenocarcinoma characteristic aberrations in lung cancer, in all adenocarcinoma and adenosquamous carcinoma cases, to explore the genes involved in telomerase activation in TP53/RB1 intact tumors (Table I).

EGFR mutations were detected in 8 of 42 (19.0\%) adenocarcinomas and none of 4 adenosquamous carcinomas. All 6 mutations in exon 19 were 15-bp in-frame deletions of the kinase domain, 4 were delE746-A750 (3 showed 2235-2249 deletion: 1 = translation initiation site, 1 showed 2236-2250 deletion) and two were delL747-T751 (2239-2253 deletion). In exon 20, one in-frame insertion of 12 nucleotides was found as insQANP773-776 (2317-2328 insertion CAGGCGAA CCCC). One tumor had a T G missense mutation L858R in exon 21. Most of these mutations have previously been reported, with the exception of the in-frame insertion in exon 20 . There was no tumor that had bi-allelic EGFR mutations.

$E G F R$ amplification was evaluated by quantitative realtime PCR in all adenocarcinoma and adenosquamous carcinoma tissues with 27 corresponding adjacent normal lung tissues as control. Since the differences in threshold cycle $(\mathrm{Ct})$ between control gene TFRC and EGFR were $<0.8$ in all adjacent normal lung tissues examined (-0.531-0.796; median $\leq 0.3$ ), we considered the tumors with a $\mathrm{Ct}$ difference $>0.8$ as having EGFR amplification (Fig. 2, cases with asterisk). According to this criteria, 5 of 42 adenocarcinomas (11.9\%), including 3 with EGFR mutations, but no adenosquamous carcinomas, were determined as having EGFR amplification, and this result was confirmed by using another control gene COG5, which locates in the opposite arm of the same chromosome 7 , except for case 38 , indicating the feasibility of this cut-off value.

In $18(42.9 \%)$ of 42 lung adenocarcinomas, a known silent single nucleotide polymorphism was detected at nucleotide 2361 (G/A; Q787Q) in exon 20 (17 heterozygotes and one homozygote; allele frequency, $22.6 \%$ ) and 1 heterozygote $(25 \%)$ in 4 adenosquamous carcinomas. The allelic balance observed in heterozygotes was compatible with the amplification data obtained by real-time PCR.

The allelic distribution of EGFR intron 1 repeat polymorphism in adenocarcinoma patients was determined by fragment analysis (Fig. 3). The incidence of repeat number was $(\mathrm{CA}) 15=6(7.1 \%),(\mathrm{CA}) 16=10(11.9 \%),(\mathrm{CA}) 17=3$ $(3.6 \%),(\mathrm{CA}) 18=1(1.2 \%),(\mathrm{CA}) 19=0,(\mathrm{CA}) 20=59(70.2 \%)$, (CA) $21=1(1.2 \%),(\mathrm{CA}) 22=3(3.6 \%)$ and $(\mathrm{CA}) 23=1(1.2 \%)$, while that in adenosquamous carcinoma was (CA)16=1 and (CA) $20=7$. Data of allelic balance was compatible with the EGFR amplification classification obtained by real-time PCR.

$K R A S$ codon 12 mutation was found in 2 adenocarcinomas and a codon 13 mutation was found in 1 adenosquamous carcinoma (Table I). 


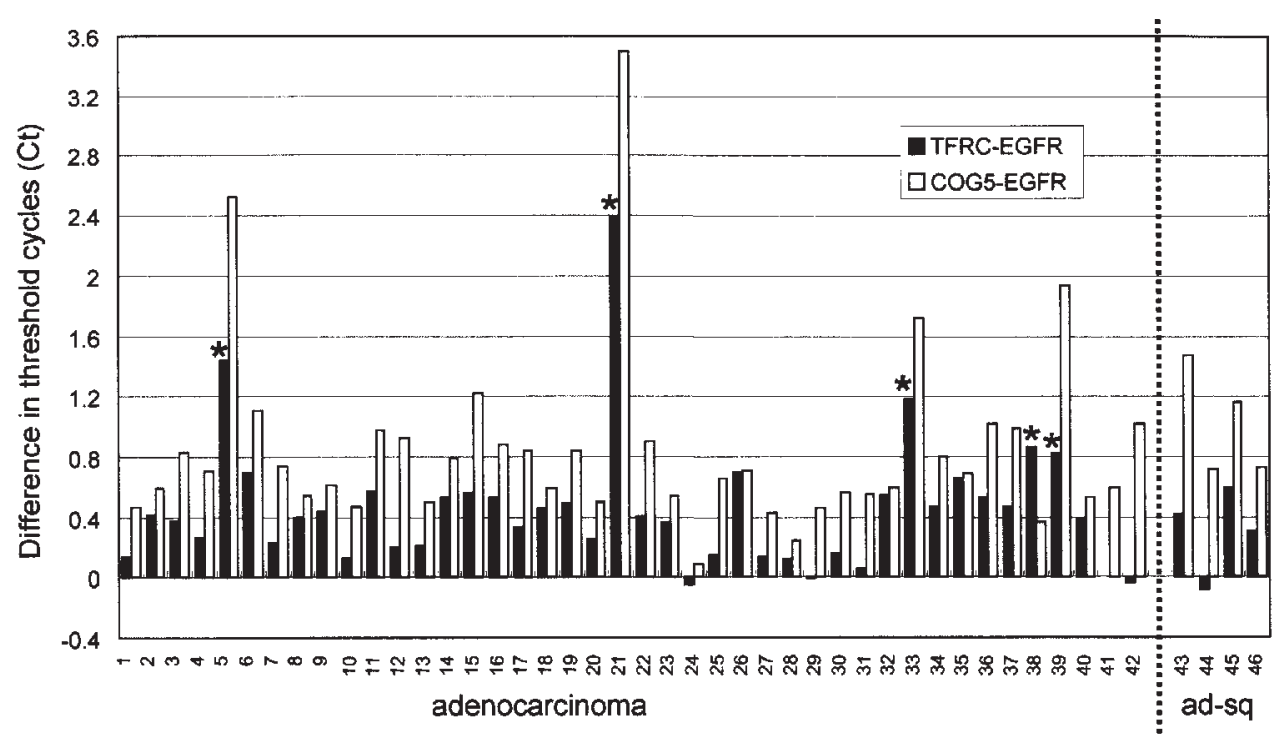

Figure 2. Detection of EGFR amplification by TaqMan quantitative real-time PCR system. The vertical value is the difference in threshold cycles (Ct) between EGFR and different chromosome control gene TFRC (closed bar) or different arm of the same chromosome 7 control gene COG5 (open bar). EGFR amplification was defined when the $\mathrm{Ct}(T F R C)$-Ct $(E G F R)$ was $\geq 0.8$ ( 5 cases with asterisk). This cut-off value was based on the differences in the adjacent noncancerous lung tissues.

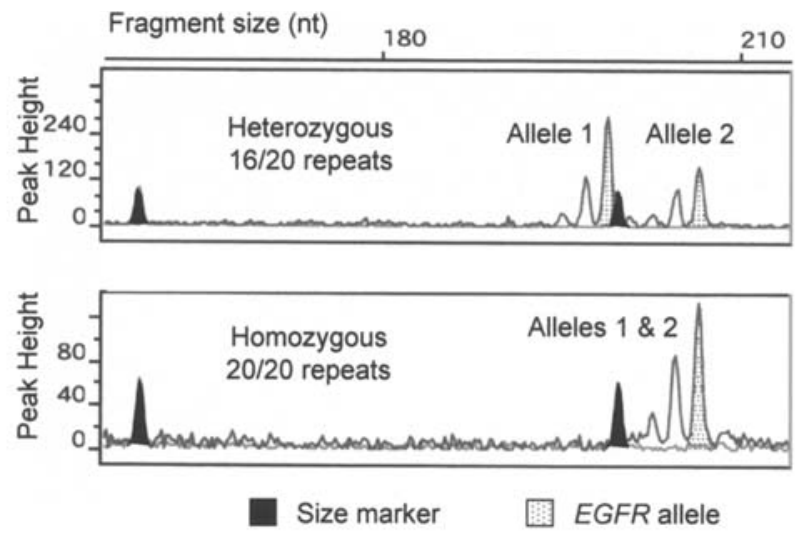

Figure 3. Genotyping of EGFR intron 1 polymorphism by fragment analysis. (CA)n repeat number was determined by the fragment size. Allelic imbalance was defined when the peak height ratio of heterozygous bands was $<50 \%$ or $>200 \%$ of expected ratio calculated from the normal cells.

Table II. Relationship between genetic aberrations in 42 adenocarcinomas of the lung ( $\mathrm{p}$-values calculated by Fisher's exact test).

\begin{tabular}{lcccr}
\hline & $T P 53$ & $R B 1$ & $1 \mathrm{p} 34 \mathrm{del}$ & $\begin{array}{c}\text { EGFR } \\
10\end{array}$ \\
Aberration no. & 15 & 11 & 14 & 10 \\
\hline TP53 & - & 0.0004 & 0.0148 & $>0.9999$ \\
RB1 & - & - & 0.0025 & 0.4103 \\
$1 \mathrm{p} 34 \mathrm{del}$ & - & - & - & 0.2586 \\
\hline
\end{tabular}

Relationship between EGFR activating aberrations (mutation and/or amplification) and other genetic aberrations in adenocarcinoma. In overall, EGFR mutations and/or amplification were found in 10 adenocarcinomas, but not in 4 adenocarcinomas. As shown in Table II, whereas the aberrations in TP53, $R B 1$ and 1p34-pter were mutually related, EGFR aberrations showed no significant relationship to either of them (Table II). Although KRAS mutation frequency (2 cases) was too small for statistical analysis, it occurred in tumors with TP53 but not EGFR aberrations. Furthermore, while neither KRAS mutation nor 1p34-pter deletion was found in the distinct adenocarcinoma subset with high telomerase activity without TP53 or $R B 1 \mathrm{LOH}, E G F R$ in-frame deletion with amplification was observed in one case of this subset. Also EGFR polymorphisms in intron 1 and exon 20 showed no relationship with EGFR activating aberrations or other genetic events.

\section{Discussion}

In lung cancer, one third of non-small cell lung cancer (NSCLC) and most small cell lung cancer (SCLC) tissues have strong telomerase activity similar to that of immortal cancer cell lines (3). One model of telomerase activation in cancer cells is that many serial and clonal selections accumulating multiple genetic aberrations promote additional cell divisions and require activation of telomerase to continue cell division. In fact, SCLC shows abnormalities in chromosomes $3 \mathrm{p}, 13 \mathrm{q}$ (RB1 locus), and 17p (TP53 locus) more frequently than NSCLCs (1). In the present study, we demonstrated that there are two subsets in lung adenocarcinomas with high telomerase activity: some adenocarcinomas with high telomerase activity had both TP53 and RB1 aberrations as observed in most squamous cell carcinomas or SCLCs, while the remaining half of adenocarcinomas with high telomerase activity had neither (Fig. 1). For the latter subset, no possible factors that might promote telomerase activation have been found. Since EGFR activating aberrations (mutations and/or amplification) are primarily found in a distinct population with adenocarcinoma of the lung $(9,18,19,28,29)$, we investigated the 


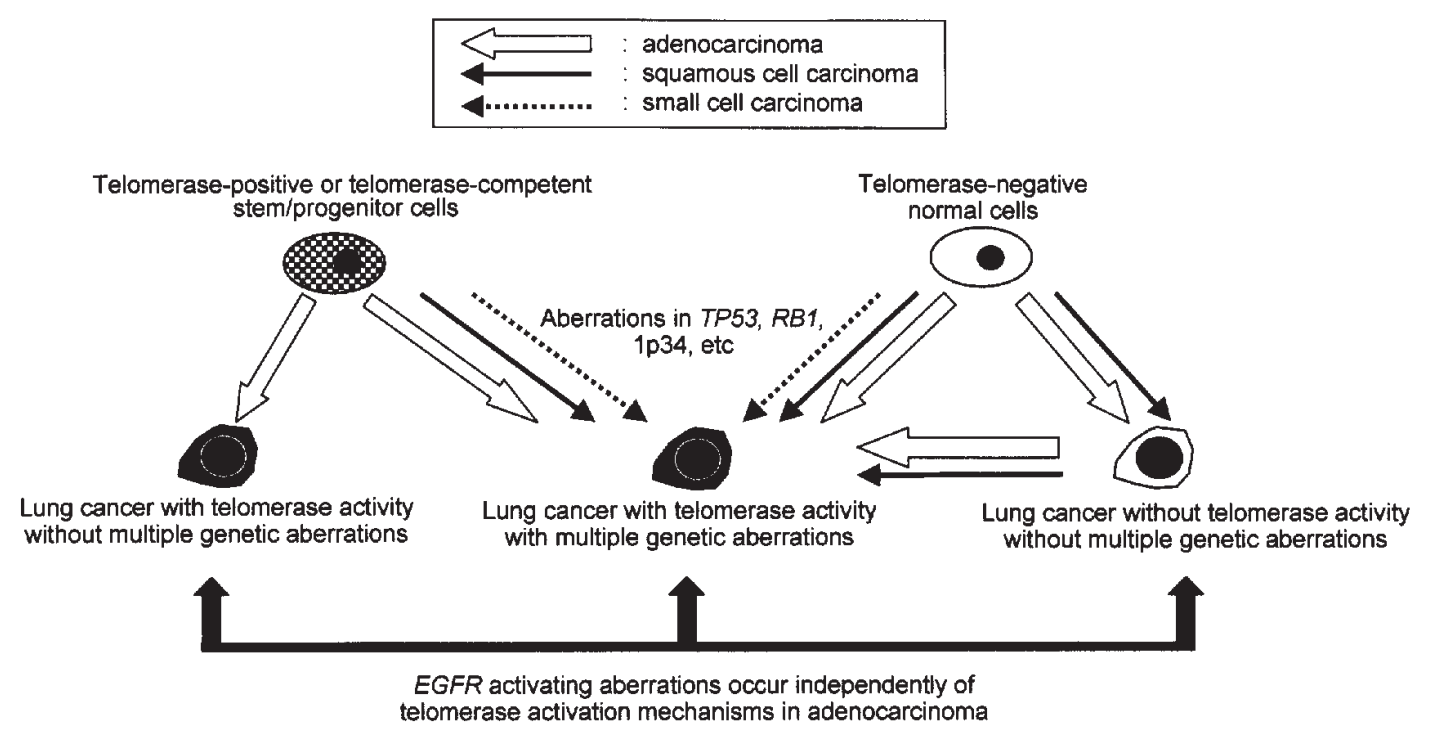

Figure 4. Our hypothesis on the telomerase activation mechanism in lung cancer. Only in adenocarcinoma is there a distinct subset with high telomerase activity without any common genetic aberrations, that may have arisen from a telomerase-positive or telomerase-competent cell, like a stem cell that has low/nil telomerase activity but can upregulate it upon proliferation. Meanwhile, EGFR activating aberrations occur in any subset of lung adenocarcinoma independently of other genetic aberrations or telomerase activation mechanisms.

relationship between EGFR activating aberrations and adenocarcinoma subgroups classified by telomerase activation mechanisms. Then we found that one case had an in-frame deletion in EGFR among the 7 adenocarcinoma cases with high telomerase activity without TP53/RB1 LOH, while the remaining 6 cases in this subset still showed no genetic aberrations. Furthermore, whereas the aberrations in TP53, $R B 1$ and 1p34-pter were mutually related in all adenocarcinomas examined, EGFR aberrations showed no relationship to either of them (Table II). These findings indicate that EGFR activating aberrations occur independently with other genetic aberrations or telomerase activation in carcinogenesis of lung adenocarcinoma, and the possibility that the distinct subset of lung adenocarcinoma with high telomerase activity without any common genetic aberrations may have arisen from a telomerase-positive or telomerase-competent cell, like a stem cell (30) that has low/nil telomerase activity but can upregulate it upon proliferation (Fig. 4).

In conclusion, we demonstrated that activation of EGFR pathway, EGFR mutation and/or amplification, may be involved in both carcinogenesis mechanisms of lung adenocarcinoma in which telomerase is activated through TP53/RB1 aberrations or without them. There is no relationship between EGFR mutation and/or amplification and other genetic aberrations common in lung cancer. Elucidation of the telomerase activation mechanism in the characteristic subset of adenocarcinoma with high telomerase activity without any genetic aberrations might shed light on cancer stem cell study in solid tumors.

\section{Acknowledgements}

For providing sample tissues, we are very grateful to Professor K. Inai at the Department of Pathology and Professor N. Kohno at the Department of Molecular and Internal Medicine, Hiroshima University and Drs N. Senoo (Hiroshima City
Hospital), M. Nishiki, Y. Matsuura and T. Toge (Hiroshima University at the time of sample preparation). We also thank Ms. I. Fukuba, Ms. K. Nukata and Ms. M. Wada in our departments, for their technical support. Part of this study was carried out at the Department of Molecular and Internal Medicine and the Analysis Center of Life Science, Hiroshima University. This study was partly supported by Grants-in Aid for Scientific Research from the Ministry of Education, Culture, Science, Sports and Technology, and the Ministry of Health, Labour and Welfare of Japan.

\section{References}

1. Minna JD, Roth JA and Gazdar AF: Focus on lung cancer. Cancer Cell 1: 49-52, 2002.

2. Miller YE: Pathogenesis of lung cancer: 100 year report. Am J Respir Cell Mol Biol 33: 216-223, 2005.

3. Hiyama K, Hiyama E, Ishioka S, Yamakido M, Inai K, Gazdar AF, Piatyszek MA and Shay JW: Telomerase activity in small-cell and non-small-cell lung cancers. J Natl Cancer Inst 87: 895-902, 1995.

4. Kawashima T, Kagawa S, Kobayashi N, Shirakiya Y, Umeoka T, Teraishi F, Taki M, Kyo S, Tanaka N and Fujiwara T: Telomerasespecific replication-selective virotherapy for human cancer. Clin Cancer Res 10: 285-292, 2004.

5. Seimiya H, Muramatsu Y, Ohishi T and Tsuruo T: Tankyrase 1 as a target for telomere-directed molecular cancer therapeutics. Cancer Cell 7: 25-37, 2005.

6. Shay JW and Wright WE: Telomerase therapeutics for cancer: challenges and new directions. Nat Rev Drug Discov 5: 577-584, 2006.

7. Miyazu YM, Miyazawa T, Hiyama K, Kurimoto N, Iwamoto Y, Matsuura H, Kanoh K, Kohno N, Nishiyama M and Hiyama E: Telomerase expression in non-cancerous bronchial epithelia is a possible marker of early development of lung cancer. Cancer Res 65: 9623-9627, 2005.

8. Hiyama K, Ishioka S, Shirotani Y, Inai K, Hiyama E, Murakami I, Isobe $\mathrm{T}$, Inamizu $\mathrm{T}$ and Yamakido $\mathrm{M}$ : Alterations in telomeric repeat length in lung cancer are associated with loss of heterozygosity in p53 and Rb. Oncogene 10: 937-944, 1995.

9. Normanno N, De Luca A, Bianco C, Strizzi L, Mancino M, Maiello MR, Carotenuto A, De Feo G, Caponigro F and Salomon DS: Epidermal growth factor receptor (EGFR) signaling in cancer. Gene 366: 2-16, 2006. 
10. Pao W and Miller VA: Epidermal growth factor receptor mutations, small-molecule kinase inhibitors, and non-small-cell lung cancer: current knowledge and future directions. J Clin Oncol 23: 2556-2568, 2005

11. Yarden Y and Sliwkowski MX: Untangling the ErbB signalling network. Nat Rev Mol Cell Biol 2: 127-137, 2001

12. Olayioye MA, Neve RM, Lane HA and Hynes NE: The ErbB signaling network: receptor heterodimerization in development and cancer. EMBO J 19: 3159-3167, 2000

13. Schlessinger J: Cell signaling by receptor tyrosine kinases. Cell 103: 211-225, 2000.

14. Jorissen RN, Walker F, Pouliot N, Garrett TP, Ward CW and Burgess AW: Epidermal growth factor receptor: mechanisms of activation and signalling. Exp Cell Res 284: 31-53, 2003.

15. Herbst RS and Shin DM: Monoclonal antibodies to target epidermal growth factor receptor-positive tumors: a new paradigm for cancer therapy. Cancer 94: 1593-1611, 2002.

16. Ettinger DS: Clinical implications of EGFR expression in the development and progression of solid tumors: focus on non-small cell lung cancer. Oncologist 11: 358-373, 2006.

17. Janne PA, Engelman JA and Johnson BE: Epidermal growth factor receptor mutations in non-small-cell lung cancer: implications for treatment and tumor biology. J Clin Oncol 23: 3227-3234, 2005.

18. Yokoyama T, Kondo M, Goto Y, Fukui T, Yoshioka H, Yokoi K, Osada H, Imaizumi K, Hasegawa Y, Shimokata K and Sekido Y: EGFR point mutation in non-small cell lung cancer is occasionally accompanied by a second mutation or amplification. Cancer Sci 97: 753-759, 2006.

19. Lynch TJ, Bell DW, Sordella R, Gurubhagavatula S, Okimoto RA, Brannigan BW, Harris PL, Haserlat SM, Supko JG, Haluska FG, Louis DN, Christiani DC, Settleman J and Haber DA: Activating mutations in the epidermal growth factor receptor underlying responsiveness of non-small-cell lung cancer to gefitinib. $\mathrm{N}$ Engl J Med 350: 2129-2139, 2004.

20. Sordella R, Bell DW, Haber DA and Settleman J: Gefitinibsensitizing EGFR mutations in lung cancer activate anti-apoptotic pathways. Science 305: 1163-1167, 2004.

21. Pao W, Miller V, Zakowski M, Doherty J, Politi K, Sarkaria I, Singh B, Heelan R, Rusch V, Fulton L, Mardis E, Kupfer D, Wilson R, Kris M and Varmus H: EGF receptor gene mutations are common in lung cancers from 'never smokers' and are associated with sensitivity of tumors to gefitinib and erlotinib. Proc Natl Acad Sci USA 101: 13306-13311, 2004.
22. Bianco R, Troiani T, Tortora G and Ciardiello F: Intrinsic and acquired resistance to EGFR inhibitors in human cancer therapy. Endocr Relat Cancer 12 (suppl 1): S159-S171, 2005.

23. Mendoza C, Sato H, Hiyama K, Ishioka S, Isobe T, Maeda H, Hiyama E, Inai $\mathrm{K}$ and Yamakido M: Allelotype and loss of heterozygosity around the L-myc gene locus in primary lung cancers. Lung Cancer 28: 117-125, 2000.

24. Tomizawa Y, Iijima H, Sunaga N, Sato K, Takise A, Otani Y, Tanaka S, Suga T, Saito R, Ishizuka T, Dobashi K, Minna JD, Nakajima T and Mori M: Clinicopathologic significance of the mutations of the epidermal growth factor receptor gene in patients with non-small cell lung cancer. Clin Cancer Res 11: 6816-6822, 2005

25. Bell DW, Lynch TJ, Haserlat SM, Harris PL, Okimoto RA, Brannigan BW, Sgroi DC, Muir B, Riemenschneider MJ, Iacona RB, Krebs AD, Johnson DH, Giaccone G, Herbst RS, Manegold C, Fukuoka M, Kris MG, Baselga J, Ochs JS and Haber DA: Epidermal growth factor receptor mutations and gene amplification in non-small-cell lung cancer: molecular analysis of the IDEAL/INTACT gefitinib trials. J Clin Oncol 23: 8081-8092, 2005.

26. Wang G, Brennan C, Rook M, Wolfe JL, Leo C, Chin L, Pan H, Liu WH, Price B and Makrigiorgos GM: Balanced-PCR amplification allows unbiased identification of genomic copy changes in minute cell and tissue samples. Nucleic Acids Res 32: E76, 2004

27. Amador ML, Oppenheimer D, Perea S, Maitra A, Cusati G, Iacobuzio-Donahue C, Baker SD, Ashfaq R, Takimoto C, Forastiere A and Hidalgo M: An epidermal growth factor receptor intron 1 polymorphism mediates response to epidermal growth factor receptor inhibitors. Cancer Res 64: 9139-9143, 2004.

28. Paez JG, Janne PA, Lee JC, Tracy S, Greulich H, Gabriel S, Herman P, Kaye FJ, Lindeman N, Boggon TJ, Naoki K, Sasaki H, Fujii Y, Eck MJ, Sellers WR, Johnson BE and Meyerson M: EGFR mutations in lung cancer: correlation with clinical response to gefitinib therapy. Science 304: 1497-1500, 2004.

29. Shigematsu H, Lin L, Takahashi T, Nomura M, Suzuki M, Wistuba II, Fong KM, Lee H, Toyooka S, Shimizu N, Fujisawa T, Feng Z, Roth JA, Herz J, Minna JD and Gazdar AF: Clinical and biological features associated with epidermal growth factor receptor gene mutations in lung cancers. J Natl Cancer Inst 97: 339-346, 2005.

30. Armanios M and Greider CW: Telomerase and cancer stem cells. Cold Spring Harb Symp Quant Biol 70: 205-208, 2005. 